\title{
Kajian Cemaran Bakteri Patogen Pada Produk Olahan Ikan
}

\section{Study of Phatogen Bacteria Contaminant on Fish Proccessed Product}

\section{Dewi Sartika*, Sri Hidayati, dan Hardianti Fitriani}

\author{
1) Jurusan Teknologi Hasil Pertanian Fakultas Pertanian Universitas Lampung \\ *E-mail: dewikincai@yahoo.com
}

\begin{abstract}
Fish proccessed product is a favorite food that contain high protein in Indonesia, such as, otak-otak ikan. The aim of this research was to observe of phatogen bacteria contaminant on fish proccessed product, ex. Salmonella sp., Escherichia coli and Staphylococcus aureus. This research was had done on food proccessed product, used random sampling technicque, at traditional markets. The result data was arranged with descriptive statistic. The result research showed that contaminant of Escherichia coli was $1.54 \times 10^{2}$ colony/ $\mathrm{ml}$ at Tani market; $0.3 \times 10^{1}$ colony $/ \mathrm{ml}$ at Gudang Lelang market. Fish proccessed product was contaminated by Salmonella, too. This research found that Fish proccessed product at Tamin, Tani and Rajabas was Salmonella contaminant detected. The Fish proccessed product that content the highest level of Stahpylococcus aureus were at Tugu narket (1,07x $10^{2}$ colony $\left./ \mathrm{ml}\right)$ and Gudang Lelang market $\left(1,12 \times 10^{2}\right.$ colony $\left./ \mathrm{ml}\right)$.
\end{abstract}

Keywords: otak-otak ikan', Salmonella sp., Escherichia coli, Staphylococcus aureus

Disubmit: 20 Januari 2019; Diterima: 03 Maret 2019; Disetujui: 10 April 2019

\section{PENDAHULUAN}

Otak-otak merupakan salah satu makanan hasil olahan berbahan dasar ikan. Ikan memiliki kandungan seperti omega 3, omega 6, serta kelengkapan komposisi asam amino. Ikan mengandung asam amino essensial yang lengkap dan sangat diperlukan oleh tubuh manusia, oleh karena itu perbandingan mutu ikan sebanding dengan mutu daging dan tentunya memiliki peranan baik di dalam tubuh manusia. Penurunan cemaran mikrobia dapat dilakukan dengan menambahkan antimikroba alami (Undadraja et al, 2018) dan terapi bacteriophage (Sartika et al, 2012)

Penanganan hasil olahan yang tidak tepat mengakibatkan makanan hasil olahan ikan ini mudah dicemari bakteri patogen seperti Escherchia coli, Staphylococus aureus, dan Salmonella sp. Kontaminasi mikroba pada bahan otak-otak dapat berasal dari tempat penyimpanan, air, udara yang tidak higienis sebelum sampai kepada konsumen (Hartari et al, 2018). Menurut Sartika et al. (2016), udang sebagai bahan baku otak-otak dideteksi tercemar Salmonella sp. Cemaran bakteri juga terdeteksi pada ikan tongkol (Puri et al, 2016) dan ayam segar serta ayam potong (Sartika, et al, 2016). Cemaran ikan dan produk olahannya misalnya otak-otak ikan dapat terjadi akibat proses pengolahan, penyajian serta saat distribusi. Salah satu tempat potensi penjualan otak-otak ikan adalah pasar tradisional.

Setiap pasar tradisional memiliki kondisi lingkungan yang berbeda-beda, ada pasar tradisonal yang telah tersusun rapih sehingga tidak terlihat tumpukan sampah, serta tidak tercium aroma yang tidak sedap, dan terdapat pasar tradisional yang terlihat sampah dimana-mana, tanah becek serta terdapat banyak lalat yang berterbangan. Hal tersebut menjadi salah satu faktor pencemar potensial bagi makanan termasuk otak- 
otak ikan. penelitian ini bertujuan untuk mengetahui dan mengidentifikasi cemaran bakteri patogen (Escerichia coli, Salmonella s.p dan Sthapylococcus sureus) pada otak-otak ikan yang beredar di pasar tradisional di kota Bandar Lampung.

\section{METODE PENELITIAN}

Bahan baku yang digunakan yaitu otak-otak ikan yang dapatkan dari pasar tradisional di Bandar Lampung yaitu Pasar Tamin, Pasar Tugu, Gudang Lelang, pasar Tani Kemiling, Pasar Tempel Rajabasa dan pasar Koga. Bahan lain yang diperlukan yaitu alkohol, spiritus, media XLD, media Staphylococcus agar, Buffered Pepton Water (BPW), media VRBA (Violet red bird agar), dan lain-lain. Alat-alat yang digunakan dalam penelitian ini yaitu cawan petri, buret, autoklaf, coloni counter, incubator, mortar/blender, batang gelas melengkung, tabung reaksi, Erlenmeyer, micro pipet dan alat-alat pendukung lainnya.

Penelitian ini menggunakan metode deskriptif dengan tiga kali ulangan dan pengamatan yang dilakukan meliputi nilai pH, uji kuantitatif Escherichia coli, uji kualitatif Salmonella sp., dan uji kuantitatif Staphyloccous aureus. Pengambilan sampel dilakukan dengan teknik stratifikasi yaitu mengelompokkan lokasi pengambilan sampel berdasarkan perbedaan antara sampel satu dengan yang lain. Pasar Tradisional yang ada di Bandar Lampung adalah 13 Pasar. Berdasarkan lokasi pengambilan sampel maka diambil lah 6 pasar secara acak mewakili pasar tradisional di bandar lampung. Lokasi pengambilan sampel terpilih secara acak adalah Pasar Tamin, Pasar Tugu, Gudang Lelang, pasar tani Kemiling, Pasar tempel Rajabasa dan Pasar koga. Berdasarkan masing-masing pasar diambil dua pasar, secara acak sebagai tempat pengambilan sampel, sehingga lokasi pengambilan sampel berjumlah 6 pasar dan masing-masing pasar diambil sebanyak satu buah sampel produk otak-otak ikan. Sampel sebanyak 6 sampel diuji lanjut di laboratorium. Masingmasing sampel di uji nilai pH, Uji kuantitatif Escherichia coli, Uji kualitatif Salmonella sp, dan uji kuantitatif Staphylococcus aureus.

\section{HASIL DAN PEMBAHASAN}

Uji Kuantitatif Escherichia coli. Berdasarkan hasil peneitian didapatkan kandungan Escherichia coli yang terdapat dibeberapa pasar adalah disajikan pada Tabel 1.

Tabel 1. Hasil pengamatan bakteri Escherichia coli pada otak-otak ikan di pasar tradisional di Bandar Lampung

\begin{tabular}{lc}
\hline Nama Pasar & Jumlah bakteri terhitung (koloni/mL) \\
\hline Pasar Tamin & $3,8 \times 10^{1}$ \\
Pasar Koga & 7 \\
Pasar Tugu & 10 \\
Pasar Tani & $1,54 \times 10^{2}$ \\
Pasar Rajabasa & 9 \\
Gudang Lelang & 2 \\
\hline
\end{tabular}

Hasil uji Escherichia coli yang dilakukan terhadap otak-otak ikan curah yang terdapat di pasar tradisional di Bandar lampung ternyata sebagian memiliki kandungan Escherichia coli yang melebihi ambang batas yang ditetapkan oleh SNI: 7757-2013 yaitu sebesar <3/g atau lebih kecil dari 3 x $10^{1}$ koloni/gram, kecuali gudang lelang, dengan nilai rata-rata yang diperoleh untuk masing-masing sampel adalah pasar Tamin diperoleh nilai sebesar 3,8 x 101 koloni/ml. Sampel terakhir yang memiliki kandungan Escherichia coli terbesar yaitu Sampel dari pasar Tani yaitu sebesar $1,54 \times 10^{2} \mathrm{koloni} / \mathrm{ml}$. Sampel yang memenuhi syarat konsumsi yaitu sampel yang berasal dari pasar Koga sebanyak 7 koloni/ml, sampel yang 
berasal dari pasar Tugu 10 koloni/ml, pasar Rajabasa sebesar 9 koloni/ml dan yang terakhir sampel yang berasal dari pasar Gudang Lelang dimana kandungan bakteri Escherichia coli sebesar 2 koloni/ml.

Cemaran bakteri Escherichia coli yang besar pada produk dapat diakibatkan karena kondisi pasar yang kurang bersih serta penyajian yang kurang higienis. Hal tersebut dapat terlihat pada pasar tempat pengambilan sampel yang berasal dari pasar Tamin dan rajabasa. Pasar Tamin termasuk pasar yang tidak hiegenis, becek, serta terdapat aroma yang cukup menyengat baik dari limbah maupun barang yang sedang di jual. Di pasar ini kita dapat melihat banyaknya sampah yang tertumpuk disudut-sudut jalan, tidak jauh dari jalan tersebut terdapat pedagang yang menjual makanan. Tentu saja dengan kondisi yang sangat tidak hygiene tersebut berakibat pada banyaknya kontaminasi yang terjadi pada makanan atau jajanan yang dijual secara curah di pasar tersebut. Pasar Tempel Raja basa tidak sekotor seperti pasar Tamin, akan tetapi penataan yang kurang terpusat, makanan seperti otak-otak dijual didekat beberapa penjual ikan, telebih lagi kondisi tempat sampah yang masih tidak beraturan dapat berpeluang atau berpotensi untuk menjadi sumber cemaran Escherichia coli. Hasil ini sejalan dengan penelitian Sartika et al (2016) dan Puri et al (2016) bahwa total Escherichia coli pada daging ayam yang berasal dari pasar tradisional lebih besar dibandingkan yang berasal dari pasar modern. Pasar tradisional memiliki kebersihan yang sangat kurang baik dari segi peralatan, pekerja dan juga pengemasan daging ayam. Selain itu air yang digunakan untuk mencuci tangan tidak mengalir dan juga tidak diganti sehingga kontaminasi dari air dapat terjadi.

Kontaminasi bakteri tersebut dapat terjadi melalui kontak langsung ataupun tidak langsung dengan udara. Udara merupakan sumber kontaminasi yang paling potensial dipasar tradisional. Udara tidak mengandung mikroflora secara alami, akan tetapi kontaminasi dari lingkungan (termasuk tumpukan sampah) sekitarnya menyebabkan udara mengandung mikroorganisme. Mikroba yang terdapat diudara biasanya melekat pada benda padat misalnya debu, atau terdapat dalam droplet air.

Kandungan Escherichia coli yang besar selain diakibatkan oleh kondisi pasar juga disebabkan oleh penyajian. Sebagian besar pedagang pasar tradisional hanya meletakkan otak-otak ikan diwadah tampah besar tanpa penutup sehingga kemungkinan mudah tercemar (oleh udara), selain itu plastik yang digunakan sebagai kemasan kemungkinan telah tercemar karena letaknnya yang berdekatan dengan ikan dan dagangan lainnya (kontak langsung). Calon pembeli pun boleh memilih dengan cara memegang makanan yang akan dibeli oleh calon pembeli.

Performance Sampel otak-otak ikan yang tersedia di pasar tradisional di Bandar Lampung disajikan pada Gambar 1. Sampel diambil dari 6 pasar yang ada di Bandar Lampung yaitu pasar Gudang Lelang, pasar Tugu, pasar Tamin, pasar Tani kemiling, pasar Koga dan pasar Tempel Rajabasa. Selain kondisi pasar dan penyajian yang berpengaruh terhadap kontaminasi Escherichia coli yang tinggi, diduga juga disebabkan sanitasi dan hygiene dari penjual tersebut atau kontaminasi langsung. Menurut Puri et al (2006) bahan kontaminan berada dalam makanan melalui berbagai pembawa antara lain serangga, tikus, peralatan ataupun manusia yang menangani makanan tersebut. Makanan dari awal proses pengolahan sampai siap dihidangkan dapat memungkinkan terjadinya cemaran oleh mikroba.

Pada pasar tani Kemiling cemaran Escherichia coli tidak sebanyak di pasar yang lain, hal ini dapat disebabkan penataan pasar serta penjual yang menjaga sanitasi dan hygiene. Pasar tani kemiling, setiap tempat dipisah, dari sembako, makanan atau jajanan, hingga tempat ikan dan daging. Selain itu tumpukan sampah yang terlihat sangat sedikit. Hal tersebut diakibatkan oleh pembuangan sampah pasar telah dipusatkan di suatu tempat. Pasar ini hanya beroperasi minggu dan kamis sehingga penataan serta pembersihan pasar yang rutin mengakibatkan pasar rapih, bersih dan tertata dengan rapih, walaupun masih terdapat cemaran bakteri yang terdapat pada ampel otak-otak yang diuji. 


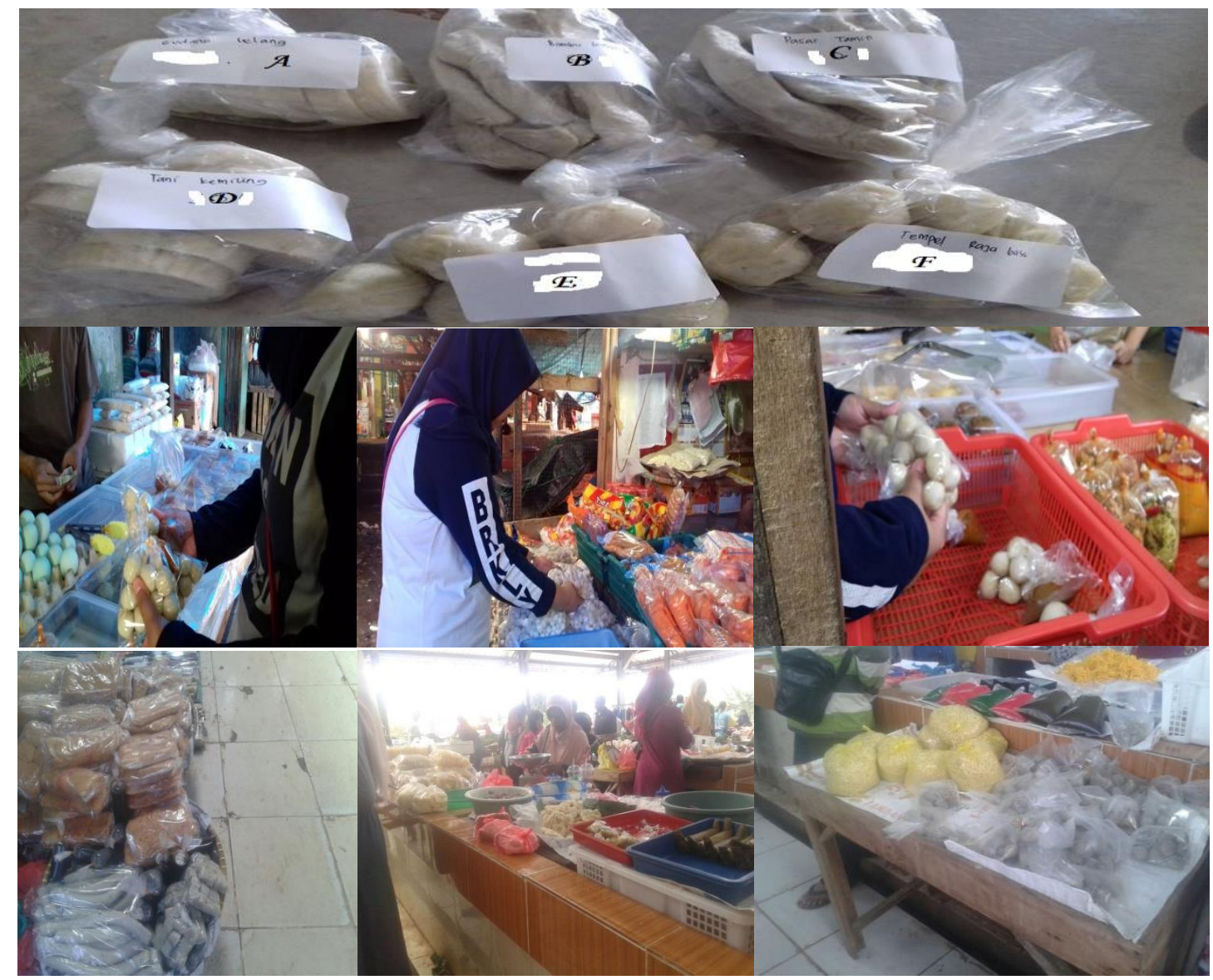

Gambar 1. Sampel otak-otak dan lokasi pengambilan sampel di 6 pasar di Bandar Lampung

Ket sampel otak-otak: $\mathrm{A}=$ Gudang Lelang $\quad \mathrm{D}=$ Tani kemiling

$$
\begin{array}{ll}
\mathrm{B}=\text { Tugu } & \mathrm{E}=\text { Koga } \\
\mathrm{C}=\text { Tamin } & \mathrm{F}=\text { Tempel rajabasa }
\end{array}
$$

Uji kualitatif Salmonella sp. merupakan bakteri patogen yang dapat mengakibatkan keracunan pada bahan pangan. Penelitian ini dilakukan uji kualitatif terhadap Salmonella $s p$. untuk mengetahui ada atau tidaknya bakteri Salmonella sp. Menurut SNI (2013) menyebutkan bahwa otak-otak ikan yang baik untuk dikonsumsi tidak boleh mengandung Salmonella sp. uji ini menggunakan media XLD agar dimana Salmonella $s p$., terlihat berwarna merah dan memiliki bercak hitam ditengah. Langkah pertama yang dilakukan pada uji ini yaitu mengencerkan sampel, setelah sampel diencerkan maka menyiapkan media XLD agar yang akan digunakan untuk isolasi bakteri. Hasil dari uji Salmonella sp. dapat dilihat pada Tabel 2.

Tabel 2. Hasil uji kualitatif Salmonella sp.pada otak-otak ikan di pasar tradisional di Bandar Lampung

\begin{tabular}{lc}
\hline Perlakuan & Hasil \\
\hline Pasar tamin & $(+)$ \\
Pasar koga & $(-)$ \\
Pasar tugu & $(-)$ \\
Pasar tani & $(+)$ \\
Pasar rajabasa & $(+)$ \\
Gudang lelang & $(-)$ \\
\hline
\end{tabular}


Berdasarkan Tabel 2 diketahui jika sampel otak-otak ikan yang berasal dari pasar tamin, pasar tani kemiling dan pasar tempel raja basa positif terdapat cemaran Salmonella $s p$, sedangkan untuk sampel yang berasal dari pasar tugu , pasar koga dan gudang lelang tidak terdapat cemaran Salmonella sp. pada otak-otak ikan.

Kontaminasi tersebut dapat berasal dari kondisi pasar yang cukup kotor banyaknya tumpukan dagangan lain atau tumpukan sampah yang memang terlihat sudah tidak asing lagi di pasar tradisional. Pasar tradisional terdapat banyak tumpukan sampah sisa dagangan yang dijual oleh pedagang, seperti insang atau sampah ikan, sayuran dan beberapa pengemas dagangan lain, selain itu lamanya kontak dengan udara mengakibatkan otak-otak ikan mengalami cemaran bakteri patogen yang cukup lama, dikarenakan udara dapat sebagai pembawa cemaran bakteri Salmonela sp. dan menempel pada makanan. Sampel otak-otak dari pasar tugu, koga serta gudang lelang tidak ditemukan Salmonella sp. hal ini diduga karena pedagang mengolah bahan baku secara benar dan berhati-hati sehingga kontaminasi bakteri jenis ini sedikit berkurang. Selain itu faktor lain yang menyebabkan bakteri Salmonella sp. tidak di temukan yaitu kondisi pengambilan serta pengujian sampel yang dilakukan pada musim hujan dimana kondisi suhu ruang relatif rendah sehingga menghambat pertumbuhan bakteri Salmonella $s p$. bakteri ini tumbuh sangat baik pada suhu hangat. Perkembangan bakteri tersebut terbilang sangat cepat, setiap selnya mampu membelah diri setiap 20 menit sekali pada suhu hangat. Sehingga infeksi bakteri ini lebih banyak terjadi pada musim panas (Arifin, 2015) oleh sebab itulah hasil uji Salmonella sp. ini beragam dan ada yang positif dan ada yang negatif dari cemaran Salmonella sp.

Uji Kuantitatif Staphylococcus aureus. Hasil uji kuantitatif bakteri Staphylococcus aureus terhadap otak-otak ikan yang dijual di pasar tradisional dapat dilihat pada Tabel 3.

Tabel 3. Hasil perhitungan bakteri Sthaphylococcus aureus pada otak-otak ikan di pasar tradisional di Bandar Lampung

\begin{tabular}{lc}
\hline \multicolumn{1}{c}{ Nama Pasar } & Jumlah total bakteri terhitung (koloni/mL) \\
\hline Pasar Tamin & $1,47 \times 10^{1}$ \\
Pasar Koga & $1,57 \times 10^{1}$ \\
Pasar Tugu & $1,07 \times 10^{2}$ \\
Pasar Tani & $1,43 \times 10^{1}$ \\
Pasar Rajabasa & $5,2 \times 10^{1}$ \\
Gudang Lelang & $1,12 \times 10^{2}$ \\
\hline
\end{tabular}

Berdasarkan uji yang dilakukan terhadap otak-otak ikan didapatkan hasil jika ternyata sampel yang berasal dari pasar tamin, pasar koga dan pasar tani kemiling kandungan cemaran bakteri Staphylococcus aureus masih dapat di toleransi karena tidak melebihi aturan yang ditetapkan oleh SNI mengenai ambang batas kandungan cemaran bakteri Staphylococcus aureus pada otak-otak ikan. Pada hasil uji ini bakteri yang terdapat pada sampel Tamin, Koga dan Tani berturut-turut yaitu 1,47 x $10^{1} \mathrm{koloni} / \mathrm{ml}, 1,57 \times 10^{1} \mathrm{koloni} / \mathrm{ml}$ dan $1,43 \times 10^{1} \mathrm{koloni} / \mathrm{ml}$, sedangkan standar yang ditetapkan oleh SNI yaitu sebesar 1,0 x $10^{2} \mathrm{koloni} / \mathrm{gram}$.

Pada sampel lainnya memiliki kandungan bakteri Staphylococcus aureus yang melebihi ambang batas toleransi yang ditetapkan oleh SNI yaitu untuk sampel yang berasal dari pasar tugu memiliki kandungan bakteri Staphylococcus aureus sebanyak $1,07 \times 10^{2} \mathrm{koloni} / \mathrm{mL}$, untuk sampel yang berasal dari pasar Tempel Rajabasa dan Gudang lelang berturut-turut yaitu 5,2 x10 $10^{1}$ koloni $/ \mathrm{mL}, 1,12 \times 10^{2} \mathrm{koloni} / \mathrm{mL}$. Sumber cemaran penyebab makanan tersebut terkontaminasi oleh bakteri Staphylococcus aureus adalah tangan penjual otakotak yang kurang bersih, wadah/peralatan/tempat menjual otak-otak ikan kurang bersih serta adanya kontaminasi dari udara yang dapat memicu adanya kontaminasi pada otak-otak ikan tersebut. 
Jurnal Penelitian Pertanian Terapan

Pengujian pH (Derajat Keasaman). Berdasarkan hasil pengujian derajat keasaman (pH) disajikan pada Tabel 4.

Tabel 4. $\mathrm{pH}$ terukur otak-otak

\begin{tabular}{lc}
\hline Nama Pasar & pH \\
\hline Pasar Tamin & 6,3 \\
Pasar Koga & 6,1 \\
Pasar Tugu & 7 \\
Pasar Tani & 6,1 \\
Pasar Rajabasa & 5,7 \\
Gudang Lelang & 7,2 \\
\hline
\end{tabular}

Hasil uji derajat keasaman $(\mathrm{pH})$ yang dilakukan terhadap sampel yang diambil dari pasar tamin, koga, tugu, tani kemiling, tempel rajabasa dan gudang lelang secara berturut-turut yaitu 6,$3 ; 6,1 ; 7 ; 6,1 ; 5,7$; dan $7,2, \mathrm{pH}$ ini termasuk normal dan memang $\mathrm{pH}$ layak konsumsi atau $\mathrm{pH}$ bahan pangan. Menurut Puri et al (2016) $\mathrm{pH}$ layak konsumsi untuk ikan dan produk olahan ikan adalah $\mathrm{pH}$ 6-7. $\mathrm{pH}$ dibawah atau diatas $\mathrm{pH}$ normal menunjukkan adanya pembentukan komponen biogenik amina akibat kerja bakteri.

\section{KESIMPULAN DAN SARAN}

Cemaran Escherichia coli tertinggi terdapat pada otak-otak ikan yang berasal dari pasar Tani sebesar $1,54 \times 10^{2} \mathrm{koloni} / \mathrm{ml}$ dan terendah adalah otak-otak yang berasal dari pasar Gudang Lelang $0,3 \times 10^{1}$ koloni/ml. Cemaran Salmonella sp. terdapat pada otak-otak ikan yang berasal dari pasar Tamin, pasar Tani dan pasar Rajabasa. Sedangkan cemaran Sthapylococcus aureus terendah terdapat otak-otak ikan yang berasal dari pasar Tani yaitu sebesar $1,43 \times 10^{1} \mathrm{koloni} / \mathrm{ml}$ dan yang tertinggi berasal dari Gudang Lelang yaitu sebesar $1,12 \times 10^{2} \mathrm{koloni} / \mathrm{ml}$.

Tingginya cemaran Escherichia coli pada otak-otak ikan yang berasal dari pasar tani, mengindikasikan perlu dilakukan pembinaan dan sosialisasi kepada para produsen otak-otak atau industri rumah tangga mengenai sanitasi dan hygiene yang baik pada saat pengolahan dan penyajian otak-otak, sehingga tidak tercemar oleh bakteri yang berbahaya bagi kesehatan.

\section{DAFTAR PUSTAKA}

Arifin, I. M. 2015. Deteksi Salmonella sp pada Daging Sapi di Pasar Tradisional dan Pasar Modern di Kota Makassar, in Unhas, pp. 675-679. Available at: https://peternakan.litbang.pertanian.go.id/ fullteks/ semnas/pro15-91.pdf?secure $=1$.

SNI. 2013. Otak-otak ikan SNI 7757-2013. Http://16438_SNI7757-2013_otak-otakikan_web.pdf.

Sartika, D, Sutikno, S., Yuliana, N., dan Syarifah R M. 2019. Identifikasi Senyawa Antimikroba Alami Pangan Pada Ekstrak Kulit Buah Naga Merah Dengan Menggunakan GC-MS. J. Tek. \& Ind. Hasil Pertanian 24(2).

Sartika, D, Sri Budiarti, Mirnawati Sudarwanto. 2012. Phage Fr38 Treatment On Sprague Dawley Rat Inferred From Blood Parameters And Organ Systems. HAYATI J. of Biosci. 19(3): 131-136. EISSN: 2086-4094.

Sartika D, Susilawati, and Anjung MUK. 2016. Survey Of Salmonella Contaminated Vannamei Shrimp In Lampung. Proceeding of The 1st onference echnology on Biosciences and Social Sciences 2016. 17th-19th 2016. Convention Hall, Andalas University. ISBN 978-602-6381-22-4. Padang-Sumatera Barat. Pp:351-357. 
Hartari, WR, Sartika D, and Suharyono AS. 2018 (publ). Using Ceara Rubber as Natural Anti-Microbe in Reducing Contamination of Staphylococcus aureus, Salmonella sp., Vibrio sp. and Escherichia coli in Mackerel Tuna Fish (Euthynnus affinis).Proceeding International Conference On Cassava, Bandar Lampung, November 23rd - 24th, 2017. ISBN 978-602-0860-26-8. LPPM Unila published. pp:5459

Puri, AA, Sartika, D Dan Subeki. 2016. Survei Cemaran Mikrobia Dan Mutu Ikan Tongkol (Euthynnus Affinis) Segar. Inovasi Dan Pembangunan-Jurnal Kelitbangan 04(02):147-161. ISSN: 2302-4399

Sartika, D, Susilawati Dan Arfani, G. Identifikasi Cemaran Salmonella Sp. Pada Ayam Potong Dengan Metode Kuantifikasi Di Tiga Pasar Tradisional Dan Dua Pasar Modern Di Kota Bandar Lampung. Jurnal Teknologi Industri \& Hasil Pertanian 21(2): 89-96. ISSN: 2302-4399

Sartika D, Erna, M, dan Marliena, L. 2016. Survei Cemaran Mikrobia Dan Mutu Daging Ayam (Gallus Gallus Domesticus) Segar. Inovasi Dan Pembangunan - Jurnal Kelitbangan 04(02):162-180. ISSN: 2302-4399

Undadraja, B and Sartika, D. 2018 (publ). Identifying Chemical Compound in Ceara Rubber Skin Which Is Potential To Be Natural Anti-Microbe By Using Gas Chromatography-Mass Spectrometry (GCMS). Proceeding International Conference On Cassava, Bandar Lampung, November 23rd - 24th, 2017. ISBN 978-602-0860-26-8. LPPM Unila published. pp: 24-27. 